Chimia $45(1991) 3-8$

(c) Schweiz. Chemiker-Verband; ISSN ö009-4293

\section{Spherosiloxanes and Spherometallosiloxanes}

\author{
Heribert Bürgy ${ }^{a}$ ), Gion Calzaferri $\left.{ }^{a}\right)^{*}$, Daniel Herren ${ }^{a}$ ), and Alexandre Zhdanov ${ }^{b}$ )
}

Abstract. Spherosiloxanes are regularly built spherical silsesquioxanes of the general formula $\left(\mathrm{RSiO}_{3 / 2}\right)_{n}(n=8,10,12, \ldots)$. A new class of materials is obtained, the spherometallosiloxanes, if some of the Si-atoms in the cage of the polyhedral siloxanes framework are replaced by metal atoms. The synthesis, the structure, and some properties of such molecules are discussed. We have discovered new synthetic routes to spherosiloxanes opening a field of many new interesting molecules. The NMR, IR, and Raman spectra are very simple due to the high symmetry of the molecules. Silanization is a highly successful form of surface modification. Silanes that are able to react with surface $\mathrm{OH}$ groups to form silyl-ether bonds can be bound covalently to a surface. We discuss surface-modification experiments based on this principle and report some recent results. Spherosiloxanes attracted our interest as model substances for investigating zeolites because of the resemblance of the framework structure of octasilsesquioxanes to the double four ring of zeolites. We focus on silver and copper zeolites, since they may be useful in an artificial photosynthesis system which is briefly explained.

\section{Introduction}

The idea of the formation of a polymeric chain from alternating $\mathrm{Si}$ - and $\mathrm{O}$-atoms led at the beginning of the 20 th century to the discovery of a new class of high-molecularweight compounds, polymers with inorganic principal molecular chains. A special class of such polymers is represented by the silsesquioxanes: siloxanes consisting of $\mathrm{RSiO}_{3 / 2}$ units may be considered as the products of the complete hydrolytic condensation of the corresponding trifunctional monomers, $\mathrm{XSiY}_{3}$ with $\mathrm{Y}=\mathrm{Hal}, \mathrm{OH}, \mathrm{OR}$, OCOR, etc. The first reports on such compounds date back to the second half of the last century, when attempts were undertaken to synthesize the $\mathrm{Si}$-analogues of the carboxylic acids. The compounds obtained by hydrolysis of $\mathrm{XSiCl}_{3}(\mathrm{X}=\mathrm{H}$ and $\mathrm{C}_{6} \mathrm{H}_{5}$ ) were mistaken for anhydrides [1]. The polymer-like character of the so formed siloxanes was discovered in 1914 [2]. Only 1946 , the first volatile so-called spherosiloxane, namely the octa(methylsilsesquioxane), was isolated [3]. Spherosi]oxanes are regularly built spherical silsesquioxanes of the general formula $\left(\mathrm{RSiO}_{3 / 2}\right)_{n}(n=8,10,12, \ldots) \mathbf{1 - 4}[4]$. The first example of an $(-\mathrm{O})_{3} \mathrm{Si}-\mathrm{X}+\mathrm{Y} \rightarrow$ $(-\mathrm{O})_{3} \mathrm{Si}-\mathrm{Y}+\mathrm{X}$ substitution in spherosiloxanes $\left(\mathrm{XSiO}_{3 / 2}\right)_{8}$ leading directly to the

\footnotetext{
* Correspondence: Prof, G. Calzaferri

a) Institute of Inorganic and Physical Chemistry

University of Bern

Freiestr. 3, $\mathrm{CH}-3000$ Bern 9

b) Nesmejanov Institute of Organoelement Compounds Academy of Sciences of the U.S.S.R.

28 Vavilov Str., U.S.S.R.-I 17334 Moscow B-334
}

formation of an $(-\mathrm{O})_{3} \mathrm{Si}-\mathrm{C}$ bond has been found recently [5]. This reaction will lead to a great number of new oligosilsesquioxanes. If a part of the Si-atoms in the cage of the polyhedral siloxane framework of spherosiloxanes is replaced by metal atoms, a new class of materials is obtained, the spherometallosiloxanes [6].

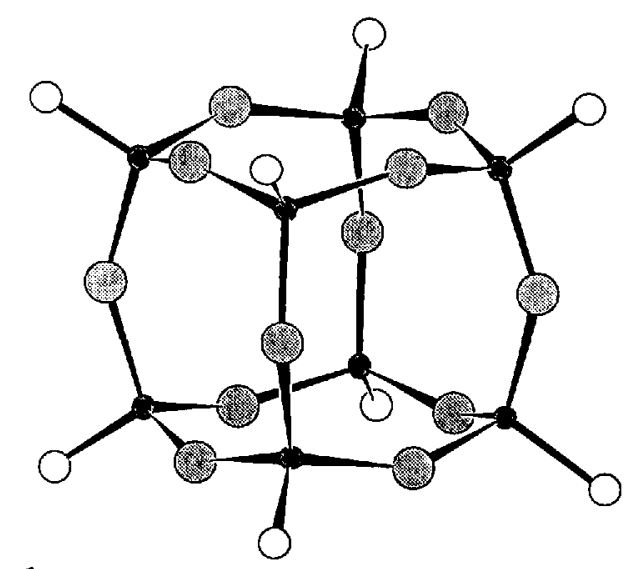

1

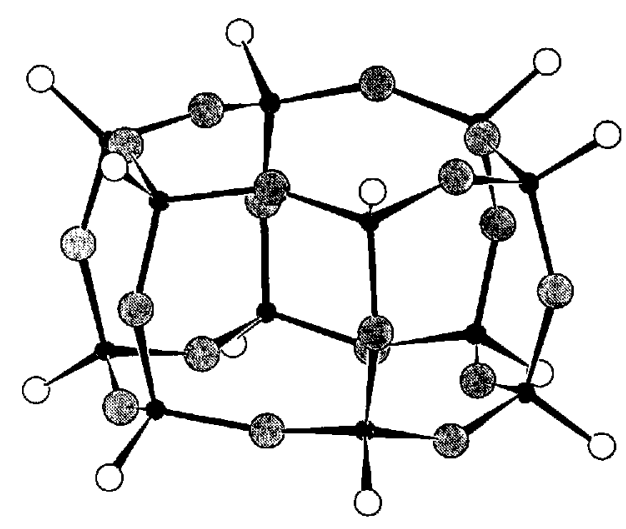

3
Synthesis

The routes to spherosiloxanes can be divided into three main groups represented in the Scheme, depending on the nature of the starting materials.

The first group a includes reactions that result in the formation of the polyhedral framework. The hydrolytic polycondensation of trifunctional monomers is the most important type of this class. It is a complex, multistep reaction process that leads to polymers and oligomers which may contain the required spherosiloxanes. As an example for this kind of reaction, we comment on the synthesis of octa(hydridosilsesquioxane) $\left(\mathrm{HSiO}_{3 / 2}\right)_{8}(\mathbf{1}, \mathrm{R}=\mathrm{H})$ as described by Frye and Collins [7]: a solution of $(\mathrm{MeO})_{3} \mathrm{SiH}$ in cyclohexane is added over a 9-h period to a vigourously stirred reaction flask containing $\mathrm{AcOH}$ (previously saturated with $\mathrm{HCl}$ ), cyclohexane, and some conc. $\mathrm{HCl}$. The latter is acting as a catalyst. The organic phase is then washed with $\mathrm{H}_{2} \mathrm{O}$ until neutral. After evaporation of the solvent, a white material remains. This is put into a sublimation chamber. Octa(hydridosilsesquioxane) $(1, \mathrm{R}=\mathrm{H})$ contaminated with mostly deca(hydridosilsesquioxane) $\left(\mathrm{HSiO}_{3 / 2}\right)_{10}(2, \mathrm{R}=\mathrm{H})$ can be sublimated at about $100^{\circ}$. Recrystallisation from cyclohexane delivers $13 \%$ of pure $1(R=H)$. The synthesis of the higher hydridosilsesquioxanes starts with $\mathrm{Cl}_{3} \mathrm{SiH}$ in benzene [7] or toluene [8], containing concentrated $\mathrm{H}_{2} \mathrm{SO}_{4}$. The yield of sphero(hydrido-

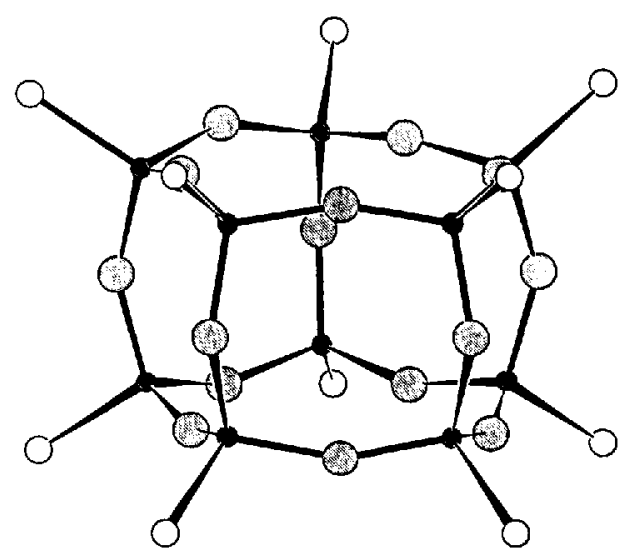

2

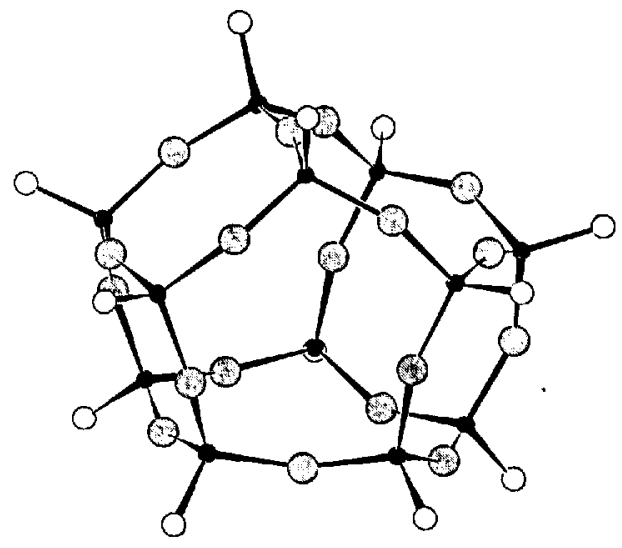

4 
Scheme

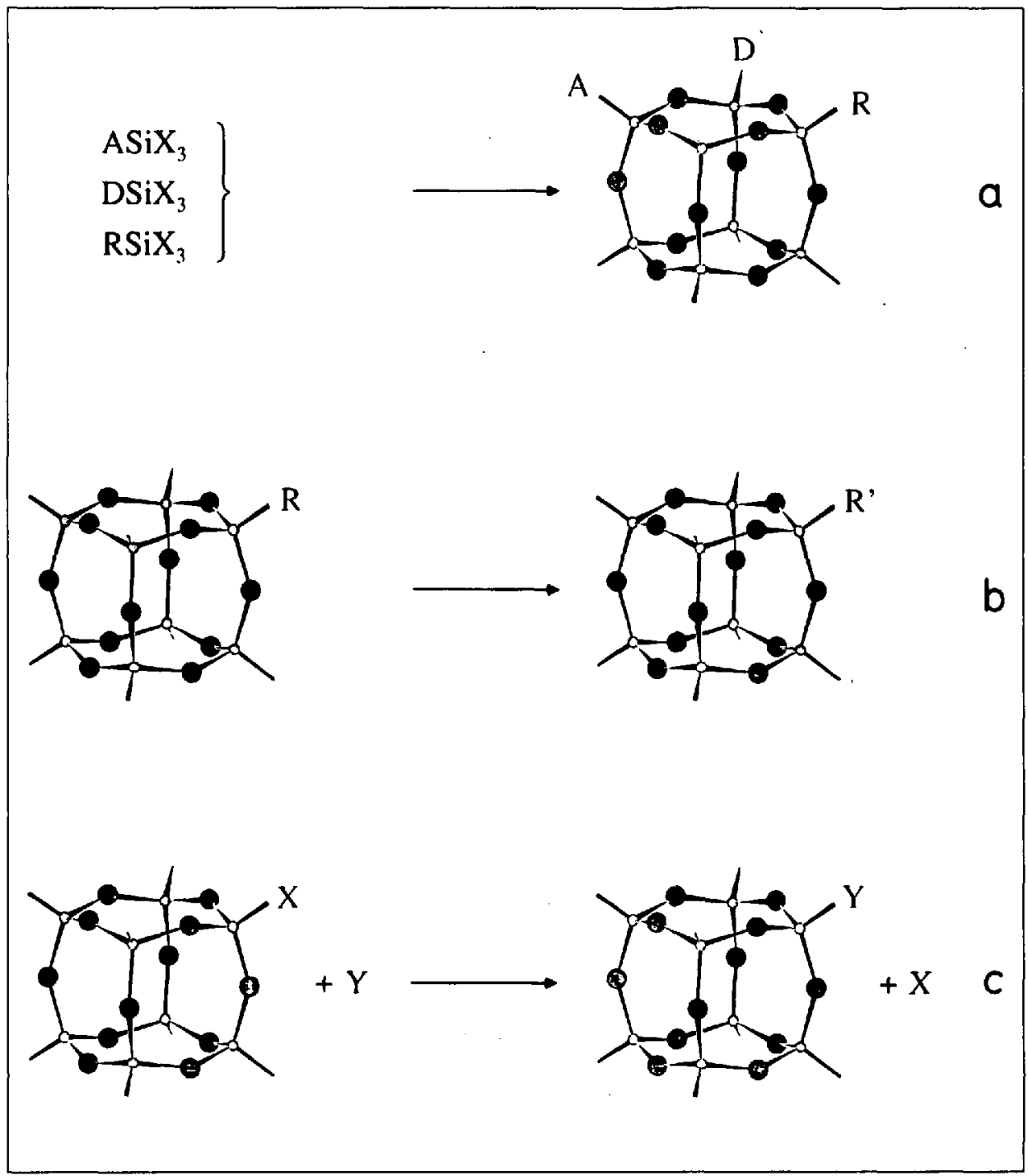

siloxanes) reported by Frye and Collins [7] is ca. $10 \%$, thereof $4 \%\left(\mathrm{HSiO}_{3 / 2}\right)_{10}, 43 \%$ $\left(\mathrm{HSiO}_{3 / 2}\right)_{12}, 39 \% \quad\left(\mathrm{HSiO}_{3 / 2}\right)_{14}, 14 \%$ $\left(\mathrm{HSiO}_{3 / 2}\right)_{16}$, and a small amount of $\left(\mathrm{HSiO}_{3 /}\right.$ 2) 18 . They can be separated by size-exclusion chromatography, a technique that allows for preparative separation [8]. By means of this polycondensation, it is possible to synthesize spherosiloxanes carrying alkyl, allyl, and aryl substituents. It is also possible to make heterosubstituted products, starting from mixtures of different trifunctional silanes. The reaction rate, the degree of oligomerization, and the yield of the polyhedral compounds formed strongly depend on $i$ ) the concentration of the initial monomer in the solution, $i i$ ) the nature of the solvent, iii) the character of the substituent(s) in the initial monomer(s), iv) the nature of the functional groups in the initial monomer(s), $v$ ) the type of the catalyst, $v i$ ) the temperature, vii) the addition of $\mathrm{H}_{2} \mathrm{O}$, and viii) the solubility of the polyhedral oligomers formed [4]. The influence of these factors, both individually or in combination, has been studied only in general, without any quantitative estimation of their effect on the reaction course. It seems likely that this traditional synthetic route to spherosiloxanes could be optimized to obtain much better yields of specific compounds. Indeed, a new synthetic route that gives a mixture of the hydridosphero- silsesquioxanes 1 and $2(\mathrm{R}=\mathrm{H})$ in $27 \%$ yield based on the starting material $\mathrm{HSiCl}_{3}$ has recently been reported by Agaskar [9] and successfully been repeated by us. Furthermore, Feher and Weller have discovered an efficient procedure for the synthesis of polyhedral aluminosilsesquioxanes [10]. Developing this procedure, they have been able to synthesize a number of very interesting molecules, such as $\left[\left(\mathrm{Me}_{3} \mathrm{SnO}\right)_{8} \mathrm{Si}_{8} \mathrm{O}_{12}\right]$ and $\left[\left(\mathrm{Me}_{4} \mathrm{SbO}\right)_{8} \mathrm{Si}_{2} \mathrm{O}_{12}\right]$ [11], vanadium-containing silsesquioxanes [12] and polyhedral oligometallasilsesquioxanes (POMSS) as models for silica-supported catalysts, $\mathrm{Cr}$ on $\mathrm{SiO}_{2}$ [13]. The latter are used for the coordination polymerization of ethylene. It is expected that a detailed study of the metalcontaining POMSS will provide new information on the chemistry of silicasupported metal catalysts.

The second class $b$ includes the reactions leading to chemical modifications of the substituents of known spherosiloxanes. Two main problems have to be mastered to make such reactions successful. The siliconoxygen framework of the spherosiloxanes must not be affected, and the substituent has to have sufficient functionality for the modification reaction. Some effort was undertaken to nitrate octa(phenylsilsesquioxane) and to brominate the latter and octa(vinylsilsesqioxane) [14]. The authors were, however, not able to control the substitution pattern of the product, and the yield was low. Recently, Feher and Budzichowski succeeded in hydrogenating aryl-containing spherosiloxanes [15] and in synthesizing functionalised spherosiloxanes of the octa $\left(p-\mathrm{XCH}_{2} \mathrm{C}_{6} \mathrm{H}_{4} \mathrm{SiO}_{3 / 2}\right)$ type ( $\mathrm{X}=\mathrm{I}, \mathrm{OH}, \mathrm{NO}_{2} \mathrm{O}, \mathrm{AcO}, p$-nitrobenzoyl, methylterephthaloyl) [16].

The third group $\mathrm{c}$ is the $(-\mathrm{O})_{3} \mathrm{Si}-\mathrm{X}+\mathrm{Y}$ $\rightarrow(-\mathrm{O})_{3} \mathrm{Si}-\mathrm{Y}+\mathrm{X}$ substitution of spherosiloxanes $\mathrm{X}_{n}\left(\mathrm{SiO}_{3 / 2}\right)_{n}$. Until recently, only three reactions of this kind have been known. The first of them is the photochlorination of $\left(\mathrm{HSiO}_{3 / 2}\right)_{8}(1, \mathrm{R}=\mathrm{H})$ to $\left(\mathrm{ClSiO}_{3 / 2}\right)_{8}$ reported by Klemperer and coworkers as late as 1985 [17]. The methoxylation of $\left(\mathrm{ClSiO}_{3 / 2}\right)_{8}$ by $\mathrm{CH}_{3} \mathrm{ONO}$ resulting in $\left(\mathrm{CH}_{3} \mathrm{OSiO}_{3 / 2}\right)_{8}$ is described in the same paper. It has been further developed by Agaskar who was successful to implement a new strategy for the synthesis of organolithic macromolecular materials (OMM's) [18]. OMM's are substances containing both silicate and organic components, with a definite chemical relationship between the two. The trimethylsilylation of various hydridosilsesquioxanes has been published two years later [19]. The fourth reaction of this class is the Dexchange of $\left(\mathrm{HSiO}_{3 / 2}\right)_{8}$ to $\left(\mathrm{DSiO}_{3 / 2}\right)_{8}$, recently found by us [20]. It is catalysed by $\mathrm{Pd}-\mathrm{C}$. The mechanism of this reaction is dictated by the rigid structure of the $\left(\mathrm{SiO}_{3 / 2}\right)_{8}$ framework, which does neither allow pseudorotation nor an attack from the back. To explain the experimental observation, a new reaction path for tetracoordinate Si has been postulated [21]. As the latest example of such a reaction, we have shown that platinum-catalysed hydrosilation of $\left(\mathrm{HSiO}_{3 / 2}\right)_{8}(\mathbf{1}, \mathrm{R}=\mathrm{H})$ can be carried out with high yield [5]. It is likely that this substitution reaction proceeds via a radical mechanism. We expect that the hydrosilation reaction is applicable to other sphero(hydridosiloxanes) such as $\left(\mathrm{HSiO}_{3 / 2}\right)_{n}$ with $n=10,12,14,16,18$. In view of its broad applicability [22], the following reactions, which lead to the formation of yet unknown spherosiloxanes, should be possible:

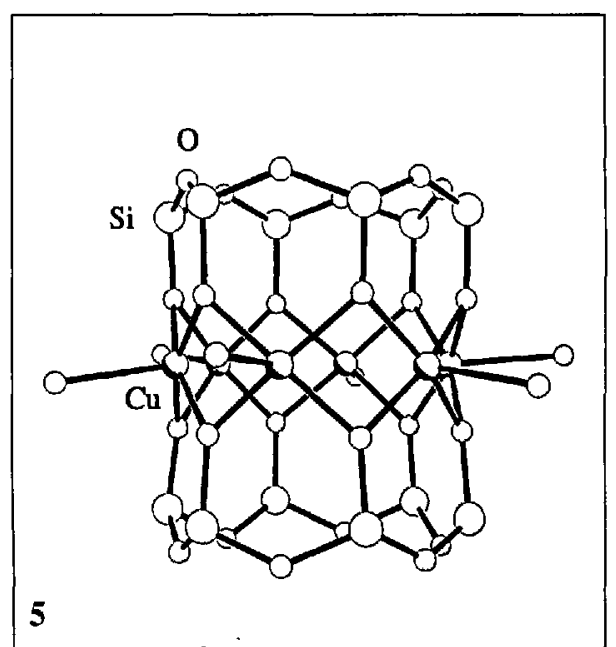


a) $\mathrm{PhCCH}+\left(\mathrm{HSiO}_{3 / 2}\right)_{n} \rightarrow\left(\mathrm{PhCHCHSiO}_{3 / 2}\right)_{n}$

b) $\mathrm{R}^{1} \mathrm{R}^{2} \mathrm{CO}+\left(\mathrm{HSiO}_{3 / 2}\right)_{n} \rightarrow\left(\mathrm{R}^{1} \mathrm{R}^{2} \mathrm{CHOSiO}_{3 / 2}\right)_{n}(n=8-18)$

c) $\mathrm{PhCN}+\left(\mathrm{HSiO}_{3 / 2}\right)_{n} \rightarrow\left(\mathrm{PhCHNSiO}_{3 / 2}\right)_{n}$

Heterosubstituted spherosiloxanes are of great interest, both from an experimental and from a theoretical point of view. Applying hydrosilation, it is easy to obtain pure mono-substituted compounds. For heterosubstituted molecules, a good separation procedure is supposed to be the key step to obtain pure compounds.

Recently, Zhdanov, Schegolikhina, and Levitsky (Nesmejanov Institute of Organoelement Compounds of the Academy of Sciences of the U.S.S.R.) have been able to synthesize a new class of materials in which a part of the Si-atoms in the cage of the polyhedral siloxane framework of spherosiloxanes is replaced by metal atoms [6]. These coloured crystalline substances are obtained in an exchange reaction between equivalent amounts of the $\mathrm{Na}$ salts of phenylsilsesquioxanes and a divalent metal chloride:

$12 / n(\mathrm{PhSiOONa})_{n}+6 \mathrm{MCl}_{2} \quad \rightarrow$

$\left(\mathrm{PhSiO}_{3 / 2}\right)_{12}(\mathrm{MO})_{6}+12 \mathrm{NaCl}(n=3-6, \mathrm{M}=\mathrm{Cu}, \mathrm{Ni}, \mathrm{Mn}, \mathrm{Co}, \mathrm{Cd})$

The compounds are of identical, three layered structure and are received in excellent yields (up to $70 \%$ after recrystallisation). The middle layer, formed by six metal atoms, is connected via $\mathrm{O}$-atoms to the $\mathrm{Si}$-atoms of the two outer laying six membered siloxane rings as shown for the copper compound 5 .

It is interesting to see that the metal atoms are coordinated by four $\mathrm{O}$-atoms of the siloxane 'crowns' and with one O-atom of a solvent molecule (e.g. alcohol). If the typical coordination number of the metal in such a compound exceeds five (e.g. six in an octahedral structure) the centre of the cage is occupied by an element which coordinates to each of the six metal atoms. An example of such a coordinating centre for the $\mathrm{Co}, \mathrm{Ni}$, $\mathrm{Mn}$, and $\mathrm{Cd}$ derivates is the chlorine ion, see 6. The negative charge of the $\mathrm{Cl}^{-}$ion is

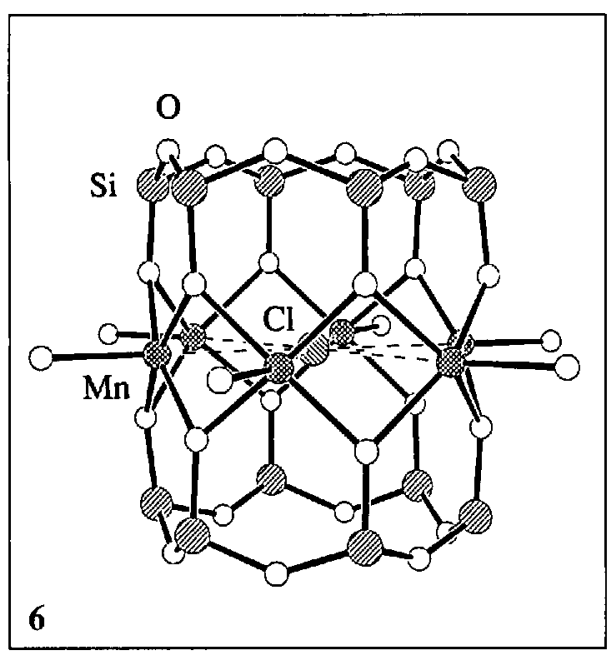
metallosiloxanes are formed:

compensated by a $\mathrm{Na}^{+}$ion laying not in the cage but near the silsesquioxane 'crown'.

Formula 5 shows the structure of the $\mathrm{Cu}^{2+}$ derivate, the coordination number of copper being five. If more than an equivalent amount of the $\mathrm{Na}$ salt of the phenylsilsesquioxane compared to the metal chloride is used, the $\mathrm{Na}$ salts of the

$12 / n(\mathrm{PhSiOONa})_{n}+4 \mathrm{MCl}_{2} \rightarrow$

$\left(\mathrm{PhSiO}_{3 / 2}\right)_{12}\left(\mathrm{Mo}_{4}\left(\mathrm{NaO}_{1 / 2}\right)_{4}+8 \mathrm{NaCl}(n=3-6, \mathrm{M}=\mathrm{Cu}, \mathrm{Ni}, \mathrm{Mn}, \mathrm{Cd})\right.$

The best known representative of these compounds is $\left(\mathrm{PhSiO}_{3 / 2}\right)_{12}(\mathrm{CuO})_{4}$ $\left(\mathrm{NaO}_{1 / 2}\right)_{4}(7)$. This fine crystalline product can be dissolved in many polar solvents (e.g. alcohols, ketones, and esters) showing a deep blue colour. It possesses interesting substructures. In one of them, each of the

\section{Properties}

Most of the known spherosiloxanes are colourless crystalline substances. Those bearing long alkyl substituents (starting from heptyl) are transparent, viscous liquids. With growing chain length of the substituents, the solubility, and volatility of the organylsilsesquioxanes increase, while the melting point decreases. Spherosiloxanes bearing alkyl substituents have a high thermal stability and a high resistance to moisture.
They are chemically inert, and resist the action of sunlight, $\mathrm{O}_{2}$ and $\mathrm{O}_{3}$. These are reasons for some of their valuable technical properties [4]. The most powerful tool for the determination of the structure of the spherosiloxanes is still single crystal $X$-ray diffraction. The structure of most of the accessible spherosiloxanes has been determined by means of this method. MS is an informative method for the investigation of spherosiloxanes. In case of octa(hexylsilsesquioxane), the most intense peak is due to the $[M-\text { hexyl }]^{+}$ion, the second intense origins from $\left[M-(\text { hexyl })_{2}\right]^{2+}$. Intense isotope ion peaks are detected an] their distribution corresponds to the natural abundance.

The high symmetry of the nearly spherical spherosiloxanes makes it very attractive to study their IR and Raman spectra and to interpret them in terms of normal coordinates. The symmetrical octasilsesquioxane $\left(\mathrm{HSiO}_{3 / 2}\right)_{8}(\mathrm{l}, \mathrm{R}=\mathrm{H})$ is especially simple. It possesses $O_{h}$ symmetry and 78 vibrational degrees of freedom. Its IR spectrum consists of six fundamental absorptions, as shown in Fig. $1 a$. The spectrum has been measured in a CCl 4 solution in a $0.2-\mathrm{mm}$ thin $\mathrm{CsI}$ liquid cell [23]. The Raman spectrum which is slightly more complicated consists of 13 fundamental vibrations. Normal coordinate analysis and analysis of the resulting potential energy distribution shows that the fundamental modes of this molecule can be described within a good approximation in terms of the internal vibrations $v(\mathrm{Si}-\mathrm{H})$, $v(\mathrm{Si}-\mathrm{O}), \delta(\mathrm{O}-\mathrm{Si}-\mathrm{H}), \quad \delta(\mathrm{O}-\mathrm{Si}-\mathrm{O})$, and $\delta(\mathrm{Si}-\mathrm{O}-\mathrm{Si})[24] . v$ is the abbreviation for stretching modes and $\delta$ is used for bending modes. The interpretation of the absorptions is as follows: $2276 \mathrm{~cm}^{-1}=v(\mathrm{Si}-\mathrm{H}), 1141$ $\mathrm{cm}^{-1}=v(\mathrm{Si}-\mathrm{O}), 880 \mathrm{~cm}^{-1}=\delta(\mathrm{O}-\mathrm{Si}-\mathrm{H}), 566$ $\mathrm{cm}^{-1}=\delta(\mathrm{O}-\mathrm{Si}-\mathrm{O}), 465 \mathrm{~cm}^{-1}=v(\mathrm{Si}-\mathrm{O})$, and $399 \mathrm{~cm}^{-1}=\delta(\mathrm{O}-\mathrm{Si}-\mathrm{O})$. A more detailed analysis is in progress [25].

Vibrational spectra analysis of octa(methylsilsesquioxane) in terms of normal modes has been carried out to some extent by Kolesov etal. [26]. These authors describe anomalously high values for the non-diagonal second order force constants, i.c., the interaction constant of bonds having no common atom. They attribute their finding 

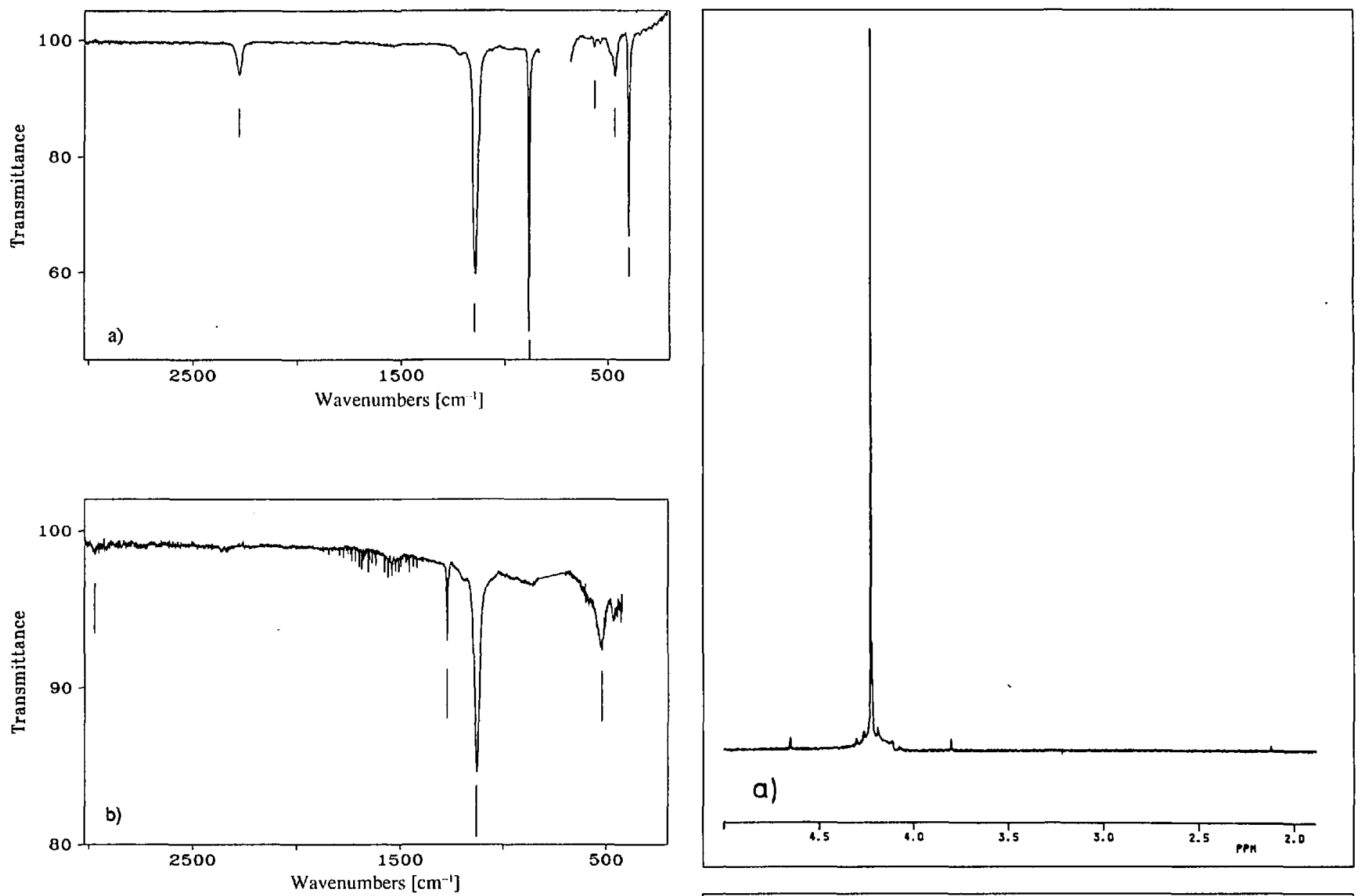

Fig. 1. a) FTIR spectra of $\left(\mathrm{HSiO}_{3 / 2}\right)_{8}$ in $\mathrm{CCl}_{4}$ at RT. b) FTIR spectra of $\left(\mathrm{CH}_{3} \mathrm{SiO}_{3 / 2}\right)_{8}$ in $\mathrm{CCl}_{4}$ at $\mathrm{RT}$. Water $\delta(\mathrm{HOH})$ rovibrational structure is also on this spectrum; see text.

to the existence of delocalized molecular orbitals. How hyperconjugation plays a role in the molecular orbitals of $(-\mathrm{O})_{3} \mathrm{Si}-\mathrm{CH}_{3}$ has bi'n discussed recently [21], and it will be interesting to carry out a more detailed analysis of the forcefield of octa(methylsilsesquioxane). The IR spectrum of $\left(\mathrm{CH}_{3} \mathrm{SiO}_{3 / 2}\right)_{8}$ is shown in Fig. Ib. For illustrative purposes, this spectrum was measured in purged mode of our FTIR spectrometer. The ro-vibrational structure belonging to the bending mode of the few remaining water molecules in the sample compartment are, therefore, clearly visible. Usually, these contributions are subtracted from the FTIR spectra reported in the literature. If measured in vacuum mode, there are no such additional absorptions, see Fig. Ia. In Fig. I $b$ only the lines indicated do belong to the $\left(\mathrm{CH}_{3} \mathrm{SiO}_{3 / 2}\right)_{8}$ molecules. The framework modes are only slightly shifted with respect to $\left(\mathrm{HSiO}_{3 / 2}\right)_{8}$. Due to the low solubility of octa(methylsilsesquioxane) in $\mathrm{CCl}_{4}$ the weak symmetrical and asymmetrical $v(C-H)$ absorption at about $2900 \mathrm{~cm}^{-1}$ is difficult to observe in this spectrum. The absorption at $1270 \mathrm{~cm}^{-1}$ corresponds to a $\delta(S i-C-H)$ mode. The ${ }^{\mathrm{l}} \mathrm{H}-$ NMR spectrum and the ${ }^{29} \mathrm{Si}$-NMR spectrum of $\left(\mathrm{HSiO}_{3 / 2}\right)_{8}(1, \mathrm{R}=\mathrm{H})$ are amazingly simple, see Fig. 2. They have been measured in a $\mathrm{CDCl}_{3} / \mathrm{CCl}_{4}$ solution. The ${ }^{1} \mathrm{H}-\mathrm{NMR}$ spectrum consists of a single peak and some weak satellites. The satellites are due to the

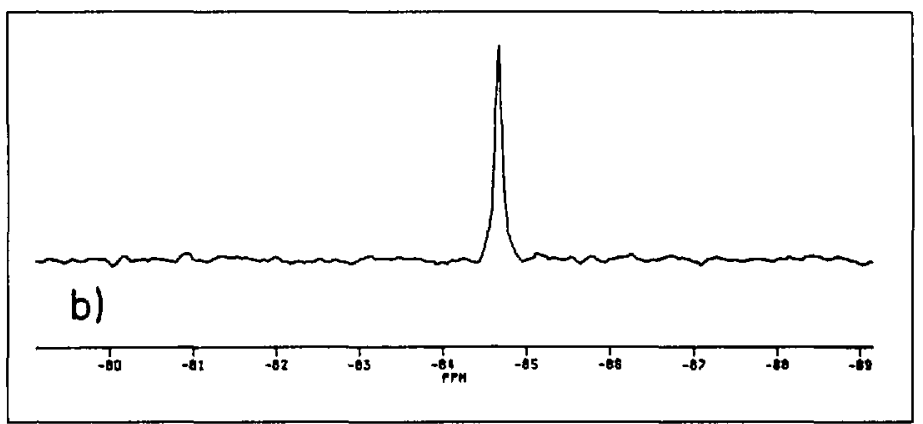

Fig. 2. a) ${ }^{l} H$-NMR spectrum of $\left(\mathrm{HSiO}_{3 / 2}\right)_{8}(1, \mathrm{R}=\mathrm{H})$. Due to the octahedral structure of the compound, it shows only one single main peak. The satellites are due to the coupling of the ${ }^{1} \mathrm{H}$ with ${ }^{29} \mathrm{Si}$. b) ${ }^{29} \mathrm{Si}-\mathrm{NMR}$ spectrum of $\left(\mathrm{HSiO}_{3 / 2}\right)_{8}$.

coupling of ${ }^{1} \mathrm{H}$ with ${ }^{29} \mathrm{Si}$. In the ${ }^{29} \mathrm{Si}-\mathrm{NMR}$ spectrum, which has been measured under proton decoupling, only a single peak is observed [23].

\section{Discussion}

Many applications of spherosiloxanes have been proposed so far, based on their structural, chemical, and physical properties. Klemperer and coworkers have used $\left(\mathrm{CH}_{3} \mathrm{OSiO}_{3 / 2}\right)_{8}$ as molecular building blocks for the synthesis of ceramic materials [17]. The rigid cube $\left(\mathrm{SiO}_{3 / 2}\right)_{8}$ core offers the possibility of generating porous yet rigid materials due to geometric factors limiting the density with which corner-linked cubes can fill space. The authors have some evidence, that the framework structure of the starting material does not degrade during the hydrolysis procedure. The hydridosilsesquioxanes $\left(\mathrm{HSiO}_{3 / 2}\right)_{n}(n=8,10,12,14$,
$16,18)$ are very interesting molecules for generating extremely thin $\mathrm{SiO}_{2}$ layers under well controlled conditions. Well defined $\mathrm{SiO}_{2}$ layers are needed for example in microelectronics, in micro-sensor technologies and in solar cells.

Others regard spherosiloxanes as models for silica surfaces [27], as precursors for studying zeolite synthesis pathways [28], as interesting candidates for photo-resist materials [15] and so on. Note that Fourier transform attenuated total intemal reflectance spectroscopy (ATR-FTIR) studies have allowed to characterize double-four-ring silicates under synthesis conditions for silicon-rich zeolites [29]. We have applied this technique in surface modification experiments [23][30][31]. Silanization is a highly successful form of surface modification. Silanes that are able to react with surface $\mathrm{OH}$ groups to form silyl-ether bonds can be bound covalently to the surface. Reactions that have been discussed for this 


$\begin{array}{lllll}\text { Surface-OH } & + & \mathrm{Cl}-\mathrm{Si} \equiv & \rightarrow & \text { Surface-O-Si } \equiv+\mathrm{HCl} \\ \text { Surface- }(\mathrm{OH})_{3} & + & \mathrm{Cl}_{3}-\mathrm{Si}- & \rightarrow & \text { Surface }-\mathrm{O}-)_{3} \mathrm{Si}-+3 \mathrm{HCl} \\ \text { Surface-OH } & + & \mathrm{RO}-\mathrm{Si} \equiv & \stackrel{\mathrm{cal}}{\longrightarrow} & \text { Surface-O-Si }+\mathrm{ROH} \\ \text { Surface-H } & + & \mathrm{H}-\mathrm{Si} \equiv & \stackrel{\mathrm{cat}}{\longrightarrow} & \text { Surface-Si } \equiv+\mathrm{H}_{2} \\ \text { Surface-OH } & + & \mathrm{H}_{2} \mathrm{C}=\mathrm{CH}-\mathrm{Si} \equiv \stackrel{\mathrm{cut}}{\longrightarrow} & \text { Surface-O-CH }-\mathrm{CH}_{2}-\mathrm{CH}_{2}-\mathrm{Si} \equiv\end{array}$

purpose are:

The last three reactions are attractive because no corrosive $\mathrm{HCl}$ is formed. They are, however, difficult to study, since a catalyst is needed. The reactions with the chlorosilanes are easy to carry out and the $\mathrm{HCl}$ formed during the reaction can be neutralized by adding a small amount of an appropriate base. For these molecules, it is relatively easy to follow the deposition kinetics out of a solution by means of ATRFTIR spectroscopy, if the substrate is sufficiently transparent in the IR. Many semiconducting crystals are sufficiently

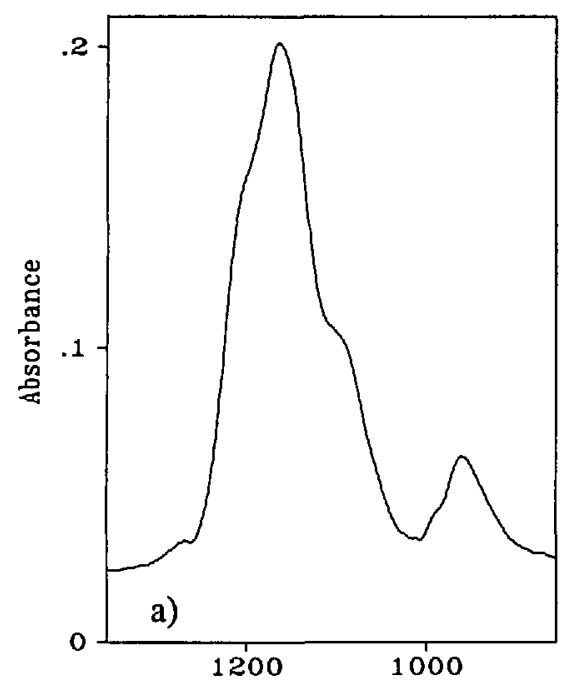

Ge-surface $(-\mathrm{O}-)_{3} \mathrm{Si}-$ phenyl $+3 \mathrm{HCl}$

The reaction conditions were as described above. We have observed a Langmuir isotherm behaviour with the typical clear saturation at approximately monomolecular coverage. As already described for the reaction with 4-[(trichlorosilyl)methyl]benzonitrile on $\mathrm{Ge}$, the reaction is slower than expected and is only completed after 4 $10 \mathrm{~h}$, depending on the conditions [23][30]. We believe that the ATR-FTIR technique and also the FTIR transmission technique developed by us for studying IR transmission of very thin zeolite pellets [33] can be applied

CHIMIA $4.5(1991)$ Nr.I/2 (Januur/lichuliar)

zeolites due to the resemblance of the framework structure of octasilsesquioxanes to the double four ring in zeolites $A$ and CoAPO-50 [35]. We focus on $\mathrm{Ag}$ and $\mathrm{Cu}$ zeolites because of their possible usefulness in an artificial photosynthesis system. The bottle neck in chemical approaches to artificial photosynthesis on a molecular level has always been the $\mathrm{O}_{2}$ production from $\mathrm{H}_{2} \mathrm{O}$

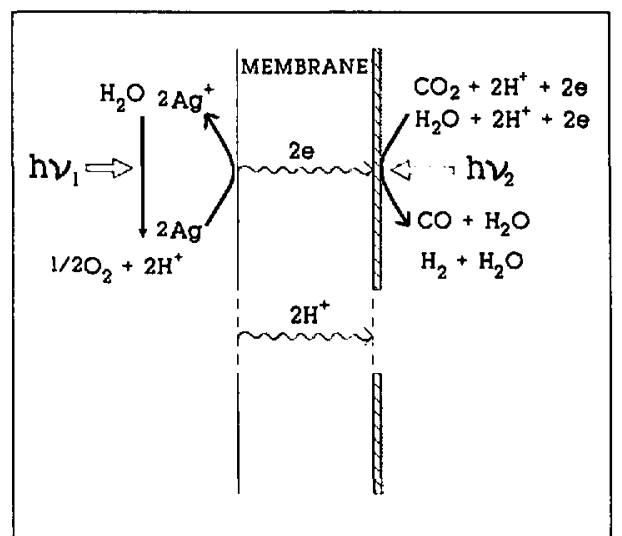

Fig. 4. Artificial photosynthesis system for the $\mathrm{H}_{2} \mathrm{O}$ splitting andlor the $\mathrm{CO}_{2}$ reduction in which two photons are involied. Electrons are moving through a modified zeolite, while protons are transported through an ion permeable membrane.

[36]. We have successfully worked on this reaction [37][38], so that it has become interesting to try and realize water splitting or $\mathrm{CO}_{2}$ reduction. Our research approach is explained in Fig. 4 [39]. For the reductive part, in which for example $\mathrm{H}_{2}$ is produced by reducing $\mathrm{H}_{2} \mathrm{O}$, we rely on systems described by other research groups [40-42], while the oxidative part needed for the $\mathrm{O}_{2}$ production by oxidizing $\mathrm{H}_{2} \mathrm{O}$ is designed according to a system developed in our laboratory. The attractive aspect of this approach is that the reductive, the oxidative, and the electron conductive parts can be studied separately. The problem to be solved is to connect the oxidative part which delivers the two electrons and the two protons to the reductive part. By covalently linking $I-\mu \mathrm{m}$ sized zeolite A particles as a dense quasi monograin layer onto an electrode, we have succeeded in preparing an $\mathrm{Ag}$ zeolite electrode which shows that the reduction and oxidation steps in the zeolite are reversible [43]. This means that we have now a single, well defined step to go in order to completely realize the process explained in Fig. 4 and with more details in [39][44][45].

This work was supported by grant No. 20-28528.90 of the Schweizerischer Nationalfonds zur Förderung der wissenschaftlichen Forschung and by grant BEWEPA 217.307 financed by the Schureizerische Bundesamr für Energien'irtschafi. 
Received: November 8, 1990

[1] a) H. Buff, F. Wohler, Amm. 1857, 104, 94; b) A Ladenburg. Ber. 1873, 6, 379.

[2] J. A. Meads, F. S. Kipping, J. Am. Chem. Soc 1914, $105,679$.

[3] D. W. Scott, J. Am. Chem. Soc 1946, 68, 356.

14] M. G. Voronkov, V. I. Lavrent'yev, Topics Curr Chem. 1982, 102, 199.

[5] D. Herren, H. Bürgy, G. Calzaferri, Helv. Chim Acta 1991, 74, 24.

[6] M. M. Levitsky, O. I. Schegolikhina, A. A Zhdanov, V. A. Igonin, Yu. E. Ovchinnikov, V.E Shklover, Yu. T. Struchkov,J.Organomet. Chem. (Russ.), in press.

[7] C. L. Frye, W. T. Collins, J.Am. Chem.Soc. 1970, 92, 5586 .

[8] H. Bürgy, G. Calzaferri,J.Chromatogr.1990,507, 481.

19] P. A. Agaskar, submitted to I. Am. Chem. Soc.

[10] F.J. Feher, K.J. Weller, Organometallics 1990, 9 , 2638.

[11] F.J. Feher, K.J. Weller, submitted to Inorg. Chem

[12] a) F. J. Feher, J. F. Walzer, Inorg. Chem., in press; b) F. J. Feher, J. F. Walzer, R. L. Blanski, submitted to J. Am. Chem. Soc.

[13] F. J. Feher, R. L. Blanski, J. Chem. Soc., Chem Commun., in press.

[14] K.Olsson, C. Grönwall, Arkiu Kemi 1961, 17,529.

[15] F. J. Feher, T. A. Budzichowski, J. Organomet Chem. 1989, 373, 153.

[16] F. J. Feher, T. A. Budzichowski, J. Organomet Chem. 1989, 379, 33.

[17] V.W. Day, W. G. Klemperer, V. V. Mainz, D. M. Millar.J. Am. Chem. Soc. 1985, 107. 8262.

[18] a) P. A. Agaskar, J. Am. Chem. Soc. 1989, 111 , 6858; b) P. A. Agaskar, Inorg. Chem. 1990, 29 1603 .

[19] P.A.Agaskar, V. W. Day, W.G. Klemperer,J.Am. Chem. Soc. 1987, 109, 5554.
[20] H. Bürgy, G.Calzaferri, Helv.Chim.Acta 1990,73, 698.

[21] G. Calzaferri, R. Hoffmann,J.Chem.Soc., Dalton Trans., in press.

[22] 1. Ojima, "The Chemistry of Organic Silicon Compounds', Eds. S. Patai and Z. Rappoport, Wiley, New York, 1989, Part II, pp. 1479-1526, and ref. cit, therein.

[23] H. Bürgy, Doctoral Thesis, University of Bern, $199 \mathrm{~L}$.

[24] P. Bomhauser, G. Calzaferri, Spectrochim. Acta, Part A 1990, 46, 1045.

[25] M. Bärtsch, P. Bomhauser, G. Calzaferri, to be submitted.

[26] B. A. Kolesov, T. N. Martynova, T.I. Chupakhina, Zh. Strukt. 1988, 29, 77.

[27] F. J. Feher, D. A. Newman, J. F. Walzer, J. Am Chem. Soc. 1989, 1/1, 1741.

[28] E. J. J. Groenen, A. G. T. G. Kortbeeck, M. Mackay, O. Sudmeijer, Zeolites 1986, 6,403.

[29] E. J. J. Groenen, C. A. Emeis, J. P. Van den Berg, P. C. de Jong-Versloot, Zeolites 1987, 474.

[30] a) G. Calzaferri, M. Gori, Helv. Chim. Acta 1985 , 68,$1617 ;$ b) G. Calzaferri, M. Gori, H.R. Grüniger, W. Spahni, 'Proceedings Photoelectrochemistry: Fundamental Processes and Measurement 'Techniques, The Electrochemical Soc.', Eds. W. L. Wallace, A. J. Nozik, S. K. Deb, and R. H. Wilson, 1982, Vol.82-3, p. 264; c) H.R. Grüniger, G. Calzaferri, Helv. Chim. Acta 1979, 62, 2547.

[31] a) R. Beer, H. Bürgy, G. Calzaferri, I. Kamber, $J$ Electron. Spec. Rel. Phen. 1987, 44, 121; b) H. Bürgy, G. Calzaferri, 1. Kamber, Mikrochim. Acta 1988, 1, 401.

[32] N. J. Harrick, 'Internal Reflection Spectroscopy', John Wiley \& Sons, New York, 1967; F. M. Mirabella, Jr., N.J. Harrick, Harrick Scientific Corpor., Ossining, NY, 1985.
[33] J. Baumann, R. Beer, G. Calzaferri, B. Waldeck, J. Phys. Chem. 1989, 93, 2292.

[34] L. M. Hananaschvili, K. A. Adrianov, 'Technology of the Organoelement Monomers and Polymers, Chimia Moscow', 1983, pp. 293-295 (Russ.).

[35] W. M. Meier, D. H. Olson, Atlas of Zeolite Structure Types', 2nd edn., Butterworths, London, 1988.

[36] T. J. Meyer, Acc. Chem. Res. 1989, 22, 163.

[37] G. Calzaferri, L. Forss, W. Spahni, Chenic in unserer Zeit 1987, 2/, 161.

[38] a) G. Calzaferri, S. Hug, Th. Hugentobler, B. Sulzberger, J. Photochem. 1984, 26, 109; b) G. Calzaferri, W. Spahni, ibid. 1986, 32, 151; c) Chimia 1986, 40, 435; d) ibid. 1987, 41, 200

[39] G. Calzaferri, Proceedings of the 3 rd intemational summerschool, 'Solar Energy 88', Ed.G. Faninger, Kaprun/Austria, IFF, Klagenfurt, 1989, p. 119.

[40] A. Harriman, M. A. West, 'Photogeneration of Hydrogen', Academic Press, London, 1982.

[41] E. Amouyal, B. Zidler, Israel J. Chem. 1982, 22, 117.

[42] J. Hawecker, J.-M. Lehn, R.Ziessel,J.Chem.Soc., Chem. Commun. 1983, 536.

[43] G. Calzaferri, K. Hädener, J. Li, J. Chem. Soc., Chem. Commum., in press.

[44] G. Calzaferri, ESA SP-240 1985, 93.

[45] G. Calzaferri, J. Li, K. Hädener, N. Gfeller, D. Herren, M. Brändle, Eight International Conference on Photochemical Conversion and Storage of Solar Energy (I.P. S. 8), Palermo, Italy, 1990, Book of Abstracts, p. 212.
Chimia 45 (199/) 8-10

() Schweiz. Chemiker-Verband; ISSN 0009-4293

\section{Bestimmung von Selen in Lebensmitteln und in Mineralien mittels Neutronenaktivierungs- analysen}

\section{Marcel Langenauer und Urs Krähenbühl*}

Abstract. The determination of Se became important, since it was recognized that this trace element is essential for the human and animal diet. Lately, it was found that most patients suffering from a cancer disease manifest very low values of Se in their blood plasma. Activation analysis is a well suited technique to measure the concentrations of $S e$ in a vast range of materials with very different concentrations. At the lower end of concentrations, a radiochemical separation of Se following the irradiation is mandatory to obtain reliable results in the determination.

\section{Einleitung}

Selen galt seit Jangem als äusserst toxisches Element. Erst 1957 wurde seine essentielle Bedeutung für den Menschen erkannt
[1]. Durch Abgabe von Selentabletten an die Bevölkerung der Keshan-Region in China konnte die Kashin-Becksche Krankheit, eine rheumatisch-athritische Erkrankung, fast vollständig eliminiert werden. Heute ist be- kannt, dass bei vielen weiteren Krankheiten wie Krebs, Leukämie oder AIDS der SeGehalt im Blut einen Mangel aufzeigt. Es ist daher wichtig, dass die Bevölkerung genügend mit Se versorgt wird. Dieses Spurenelement kommt in Fleisch, Fisch und Getreideprodukten angereichert vor [2][3], wogegen es in Gemüse, Früchten und Milchprodukten verarmt ist [3]. Der tägliche Mindestbedarf des Menschen beträgt I $\mu \mathrm{g} \mathrm{Se} / \mathrm{kg}$ Körpergewicht [2]. Im allgemeinen sind die Böden der Schweiz recht arm an Se [4]. Importiertes Getreide aus den USA oder Kanada weist einen 10 bis 100 mal höheren Gehalt an diesem essentiellen Element auf als Weizen, der in der Schweiz geerntet wurde. Eine ausreichende Versorgung der Schweiz mit Se ist Dank der Getreideimporte gewährleistet. Die Entwicklung einer

*Korrespondenz: Prof. U. Krähenbühl Laboratorium für Radiochemie Universität Bern

Frejestrasse 3, CH-3000 Bern 9 